\title{
緊急企画・大丈夫？ 河口域底質中ダイオキシン
}

\section{緊急企画にあたって}

今回,「河口域における底質中ダイオキシン類 の現状とその対策」が緊急企画の形で編集される こととなったが,はじめにそのいきさつとわが国に おけるダイオキシン問題の経緯を述べておきたい. 2002 年 8 月, 大阪で, 今日の都市域の環境問題 に対する行政・技術上の課題を行政担当者, 研究 者，技術者などが一堂に会して議論し，都市域の 環境再生に寄与することを目的として「都市域環 境問題研究会」(会長: 村岡浩爾 大阪大学名誉 教授，大阪産業大学教授）が発足した。 その第 1 回目のイヴニング・セミナーで村岡会長がコー ディネーターとなり「都市の土袞污染問題」を取 り上げ，11月開催の第 2 回目に筆者がコーディ ネーターとなり，「河口域における底質問題」を 取り上げた。ちょうど，その 4 ヶ月前の 2002 年 7 月に「ダイオキシン類による水底の底質の污染 に係る環境基準」が告示されたこともあって，時 宜を得たテーマと思われた。本特集では，そのお り話題提供を依頼した大阪市立環境科学研究所 角谷直哉氏に「大阪湾河口域における底泥污染の 実態」, 大阪市港湾局 福本 弘氏に「淩渫事業におけ る浚渫土の処分問題」, そして五洋建設(株) 車田佳 範氏に「底泥の処理対策技術」の執筆をお願いした．

ところで，ダイオキシン問題は，1960年代のべ トナム戦争で散布された枯葉剤で, ベトナムの村 民たちの間に癌や流産, 奇形児の誕生などが多発 したことで，一気に世界中の人々に注目されるよ うになった。アメリカでは既に1953年に飭によ るひよこの大量死でこの問題が始まっていたよう であるが，わが国では1983年に都市ごみ焼却炉 の飛灰の中よりダイオキシン類が検出されたのが 最初であるといわれている，その翌年から厚生省 の専門家会議で，食品等を通じて人が体内に摂取 する場合の許容基準（耐容一日椇取量 (TDI) ) の検討が始まった。当初 $100 \mathrm{pg}-\mathrm{TEQ} / \mathrm{kg}$ 体重/日 に設定されていたこの数值は, 以後, $10 \mathrm{pg}$ $\mathrm{TEQ} / \mathrm{kg}$ 体重/日に下がり, そして1998年 5 月に
WHO が 1 ～ $4 \mathrm{pg}$-TEQ $/ \mathrm{kg}$ 体重/日に変更したこ とを受けて，1999年 6 月，政府のダイオキシン対 策閣僚会議で，4 pg-TEQ $/ \mathrm{kg}$ 体重/日とすること が決定された。

そして，1999年 7 月「ダイオキシン類対策特別 措置法」が成立し, ダイオキシン類の環境基準が, 大気は $0.6 \mathrm{pg}-\mathrm{TEQ} / \mathrm{m}^{3}$, 水質 $1 \mathrm{pg}-\mathrm{TEQ} / \mathrm{L}$, 土壤 1000pg-TEQ/g と定められた。この時点では, 底質だけが未定であったが，2002年 7 月「ダイオ キシン類による水底の底質の污染に係る環境基 準」が告示され，その環境基準が150pg-TEQ/g と定められた，翌月の 8 月には，環境省から「底 質の処理・処分に関する指針」が出され，基準を 超過している污染底質の処理・処分，およびその 際の 2 次污染の防止が義務づけられることとなっ た。これを受けて，同年10月，国土交通省が「港 湾における底質ダイオキシン類対策検討委員会」 を設置し, 今年 3 月にその技術的対応策をまとめ た技術指針を出す運びとなっている。

環境省によると，1997年には7.5 kg-TEQ/年で あったわが国の総排出量が，2000年には $2.2 \mathrm{~kg}$ $\mathrm{TEQ} /$ 年になったといわれており，大気環境から も含めて海域へのダイオキシン類等有害物質の流 入は今日では少なくなったといえる。しかし，既 に排出されたダイオキシン類の一部は河口域底泥 中に蓄積しており，その濃度は，現在までの調査 によると数 $10 \mathrm{pg}-\mathrm{TEQ} / \mathrm{g}$ が通常であり，時には 除去基準である150pg-TEQ/g を超えることも珍 しくない状況にある，従って，今後は，底泥中に 蓄積されたダイオキシン類とその溶出による污染 をいかに防止するかが重要課題となる．河川や港 湾を抱える大都市自治体は，また一つ難しい問題 を背負わなければならないが，我々みんなで英知 を絞ってよい解決法を見出す必要がある，本企画 が少しでもそのことに役立てば幸いである。

小田一紀 (大阪市立大学大学院) 